\title{
THE EFFECT OF CORPORATE SOCIAL RESPONSIBILITY DISCLOSURE ON COMPANY PROFITABILITY AND REPUTATION: EVIDENCE OF LISTED FIRMS IN INDONESIA
}

\author{
Reply Gara \\ East Indonesia Union Conference of Seventh Day Adventist Church, Jl. Sarapung No. 31, Manado, 95111, \\ Indonesia \\ Email: reflygladys@yahoo.co.id
}

\begin{abstract}
Corporate social responsibility or later abbreviated to CSR has become a trend and a hot topic that is widely discussed in Indonesia. Business practices in the past that tended to have a negative impact, made the discourse on corporate social responsibility or CSR. There seems to be a paradigm shift from being initially profit oriented, where any activity must be viewed from the point of adding financial benefits or not, becoming more concernedtowards socially responsible responsibilities. This topic became even more interesting with the enactment of Law no. 40 of 2007 concerning Limited Liability Companies, (UUPT) as of August 16, 2007, has given rise to a variety of controversies and disagreements. The resultsshow thatcorporate social responsibility disclosure is significant on profitability (ROA) ofhigh profile, but not significant on low profile firms. The Corporate Social Responsibility disclosure is significant on profitability (ROE) of high profile and low profile firms. The Corporate Social Responsibility disclosure is significant on reputation of high profile and low profile firms.
\end{abstract}

Keywords: corporate social responsibility; disclosure; profitability; high profile company; low profile company; company reputation

JEL Classification: M14,M48

Article info:

Received 5 March 2020

Revised 5 March 2020

Accepted 5 March 2020

Available online 5 March 2020

\section{INTRODUCTION}

Nowadays corporate social responsibility or what is later abbreviated as CSR has indeed become a trend and become a hot topic that is widely discussed in Indonesia. Many people discuss about CSR and many firms in small or large scales and multinational or domesticare interesting and start practicing the CSR. Business practices in the past that tended to have a negative impactmade the discourse on corporate social responsibility or CSR, a necessity to change the image of an environmentally friendly business world (Sela et al. 2019). There seems to be a paradigm shift from being initially profit orientedwhere any activity must be viewed from the point of adding financial benefits or notbecoming more concerned with socially responsible responsibilities.

The CSR is the responsibility form of firms to social and environment, and the important factor considered by investors when making investment decisions (Wahongan, 2019). The presence of CSR, which should have been integrated in the company hierarchy as a strategy and management policyis needed in order to achieve a balance of business between the actors and the surrounding community. The efficiency and significance of CSR are still not fully readable by business people which makes CSR itself for some new business people 
is just a discourse and sometimes its implementation is based on community demands (Tanudjaja, 2006). The enthusiasm of caring for others and carrying out corporate social responsibility is still it is not yet part of the company's strategy and instead it is not uncommon to only be an additional part of the activity in the annual report and not the least is a public relations activity. This is because companies in essence continue to pursue their basic goals, namely maximize its profits. The decision making should thereforebe taken if it increasing the corporate profits (Khan, 2017). Many cases in Indonesia involving large firms face claims from surrounding communities, because corporate not respond to stakeholders concerns and expectations.

Financial accounting standards in Indonesia do not require companies to disclose social information, especially regarding corporate responsibility for the environment and other consequences arising from its activities. However, for companies that listed their shares on Indonesian Stock Exchange (IDX), disclosure of social activities such as CSR has been regulated in Regulation Bapepam (or Peraturan Badan Pengawas Pasar Modal dan Lembaga Keuangan) No. KEP-13/BL/2006 dated on $7^{\text {th }}$ December 2006 in lieu of Bapepam Regulation No. KEP-38/PM/1996.TheBapepamRegulation strives to provide a clear picture of management performance to the public.The regulation is expected to make management disclose other information beyond what has been required. The Financial Accounting Standards (or SAK) issued byIndonesian Institute of Accountants (or IAI)as written in the Statement of Financial Accounting Standards (or PSAK) No.1 (Revised 2004) in ninth paragraph implicitly suggests expressing responsibility for environmental and social problems. The firm also can provides additional reports such as reports on the environment and value added statementsespecially for industries where environmental factors play an important role and for industries that consider employees as the user group that plays an important role.

There have been many empirical studies about the relationship between corporate social performance and profitability that produce ambiguous results. Some of the studies have indicatedthat CSR has significant effect on profitability (Sutrisno, 2017; Rahayu, 2014) whereas others have not (Celvin and Gaol, 2015; Wardani, 2015:66; Aras et al., 2010; Priyanka, 2013:88).Moreover, disclosure of CSRcan increase and contribute to the corporate reputation from the perspective of various stakeholder (Jeffrey et al., 2018). However, the reason for corporate disclosure their CSR activity still lacks attention.Thus, the aimof this studyis to examine the link between CSR disclosure and profitability and reputation in Indonesia.

\section{LITERATURE REVIEW}

Corporate social responsibility is the actions of firms take into consideration the concerns of a wide range of corporate stakeholders and integrated principles of social and environmental sustainability into the business process (Alkababji, 2014). The commitmentsof firms is contributing sustainable economic development by considering to corporate social responsibility and focuses on the balance between company goals, social and environment aspects.Widjaja and Pratama (2008: 44) suggest that in maintaining the survival of firms then there are three things that are equally important that must be considered by companies that are interrelated and very influential for the survival of the company:

1. Economic sustainability. In implementing CSR programs, companies must fulfill their basic objectives, which are looking for maximum profits. The economic sustainability of a company is the basis for the company in maintaining social and environmental sustainability. The company will be able to maintain social and environmental sustainability if the company benefits. Sustainability economy achieved such as by way 
of profit, minimize costs and maximize sales, establish policies and strategic business promises attractive returns to investors.

2. Social sustainability. The establishment of a company in the midst of the community will certainly have an impact on the community. The presence of companies expected a bit much will uplift the welfare of the surrounding community either through recruitment or the company directly contribute to the community. With the existence of CSR to the surrounding community, the company was actually helped in terms of getting a sense of security and comfort in trying to get from the surrounding community. Social sustainability is related to the company's efforts to prioritize values that grow in the community.

3. Environmental sustainability. A good and maintained environment is the hope of all parties. Lately the world is very busy with the problem of global warming that threatens human life. In this case one of the parties being blamed is the company. The company's industrial activity is blamed as the main cause of global warming. The many demands from the public, NGOs and other international organizations that companies pay attention to environmental issues reinforce the argument that environmental sustainability is very important in maintaining the company's survival. A good and well-maintained environment can greatly support a company's activities. The issue of environmental preservation is so important especially for companies engaged in the field of natural resources.

In general, companies that have successfully implemented CSR use four stages which are planning phase, implementation phase, evaluation phase, and the reporting stage (Wibisono, 2007: 127-131).One thing that stands out from CSR practices in Indonesia is the emphasis on aspects of community development. Although CSR is not solely a Community Developmentbut this is indeed very much in accordance with the conditions and needs of our society, which is still struggling with poverty and unemployment. Government data states that poverty and unemployment in Indonesia are more than $30 \%$ of the population, while unemployment has reached 40 million people. Not to mention the low quality of education and health which are the main cause of the difficulty in breaking the poverty chain (Ambadar, 2008:7). The social accounting as an instrument of responsibility has a function as a means of controlling the activities of a business unit. The more widespread corporate social responsibility causes the need to incorporate social elements in corporate responsibility into accounting in accordance with its function as a means of accountability.

According to Sartono, (2010:122), one the financial ratio analysis is profitability which is important to measure the ability of firms in creating profits. Janra (2015) shows that the profitability has significant effect on CSR while the studies by Evandini and Harsono (2014), Purwanto (2011), and Khadifa and Chariri (2014) that use ROA asproxy of profitabilityshow that profitability has no significant effect on CSR. The study by Yuliawati and Sukirman (2015) that use ROE as proxy of profitability shows that profitability has significant effect on CSRwhile the study by Anisah (2018) shows that profitability has no significant effect on CSR.

Reputation is the way other parties view a company, a person, a committee, or an activity. Some aspects that form the elements of the company's image \& reputation include: (1) financial capability; (2) product and service quality; (3) customer focus; (4) excellence and sensitivity of human resources; (5) reliability; (6) innovation; (7) environmental responsibility; (8) responsibility social responsibility; and (9) enforcement of good corporate governance (News of PERHUMAS, 2005). The nature and type of industry of a company have been identified as potential factors determining social disclosure practices. In case to distinguish the two types of industries in high profile and low profile then Utomo (2000) defines high profile companies and low profile companies as follows: 
a. Companies in the high profile category. High profile companies as companies which have high consumer visibility, risk level and competency level.

b. Companies in the low profile category. Low profile industry consists of buildings, finance and banking, medical equipment suppliers, property, retailers, textiles and textile products, personal products, and household products.

Ayadi (2009), Yusdantara and Rahanatha (2015), and Syahriani and Siwi (2018)show that firm reputations have significant effect on CSR while Anisah (2018) shows that firm reputation has no significant effect on CSR.

\section{RESEARCH METHOD}

This study is a causality research which aims to determine the relationship and influence between two or more variables (Indriantoro and Supomo, 2004:27). This study conducts the firmswhich listed in Indonesia Stock Exchange(IDX) over period of 2017 and 2018.Data collecting methods in thisstudy is data pooling. The data used in this study are secondary data which are generally in the form of evidence, historical records or reports that have been compiled as documentary data which are published or not published (Indriantoro and Supomo, 2004:147). The secondary data types used are external data and data retrieval in the form of annual financial reports of public firms which obtained from www.idx.co.idand by visiting the Capital Market Reference Center. This study uses a simple regressionto predict the value of a dependent variable based on the value of other variables. Regression analysis can also be used to see the effect of the independent variable (X) on the dependent variable (Y). In term to find whether or not there is an influence between the independent variable $(\mathrm{X})$ and the dependent variable $(\mathrm{Y})$ then this study uses the equations as follow.

$\mathrm{Y} 1=\alpha+\beta \mathrm{X}+\varepsilon$

$\mathrm{Y} 2=\alpha+\beta \mathrm{X}+\varepsilon$

$\mathrm{Y} 3=\alpha+\beta \mathrm{X}+\varepsilon$

The Y1 is return on assets or ROA, Y2 is return on equity or ROE, Y3 is company reputation or Rep., and $\mathrm{X}$ is corporate social responsibility or CSR.

\section{RESULT AND DISCUSSION}

\subsection{Result}

Table 1 presents that the sample of this study is 60 which come from the amount of public firms in period of 2017 and 2018 which meet the criteria as sample.Table 1shows thatmean of disclosure for social responsibility onhigh profile firms is 46.90 which higher than low profile firms that only 31.35. The minimum and maximum values of high profile firms are 23 and 65while the minimum and maximum values in low profile firms are 14 and 44. The standard deviation of high profile firms is 8.069 while the low profile firms show 6.913. On those results, disclosure of corporate social responsibility for high profile firms higher than low profile firms.

Table 1. Descriptive statistics

\begin{tabular}{llrrrr}
\hline & N & \multicolumn{1}{c}{ Minimum } & \multicolumn{1}{c}{ Maximum } & \multicolumn{1}{c}{ Mean } & Std. Deviation \\
\hline ROA & 60 & -20 & 0.41 & 0.0986 & 0.11290 \\
ROE & 60 & -50 & 0.82 & 0.1704 & 0.21501 \\
Rep & 60 & 50.00 & 244800.00 & 9761.7000 & 35177.20183 \\
CSR-HP & 60 & 23.00 & 65.00 & 46.9000 & 8.06898 \\
ROA1 & 60 & -0.05 & 0.39 & 0.0275 & 0.05815 \\
ROE1 & 60 & -0.42 & 0.58 & 0.0993 & 0.11939 \\
Rep 1 & 60 & 50.00 & 42750.00 & 2188.5000 & 6059.24216 \\
CSR-LP & 60 & 14.00 & 44.00 & 31.3500 & 6.91308 \\
Valid N & 60 & & & & \\
\hline
\end{tabular}


Table 2 shows that the significance level of variables of disclosure on Corporate Social Responsibility for high profile firms is $0,010<0.05$ so it can be concluded that CSR disclosure has significantly influence ROA. The significance level of variables of disclosure on Corporate Social Responsibility for low profile firms is $0.960>0.05$ so it can be concluded that the Corporate Social Responsibility disclosure has not significantly influence ROA. Table 2 shows that the significance level of variables of disclosure on Corporate Social Responsibility for high profile firms is $0,031<0.05$ so it can be concluded that the disclosure of corporate social responsibility has significantly influence ROE. The significance level of variables of disclosure on Corporate Social Responsibility for low profile firms is $0.032<0.05$ so it can be concluded that Corporate Social Responsibility disclosure has significantly influence ROE. Table 2 also shows that the significance level of variables of disclosure on Corporate Social Responsibility for high profile firms is $0,022<0.05$ so it can be concluded that the Corporate Social Responsibility disclosure has significantly influence reputation. The significance level of variables of disclosure on Corporate Social Responsibility for low profile firms is $0.032<0.05$ so it can be concluded that the corporate social responsibility disclosure has significantly influence Reputation.

Table 2. Regression results

\begin{tabular}{llrrr}
\hline \multirow{2}{*}{ Profile } & \multicolumn{2}{c}{ Independent variable } & \multicolumn{3}{c}{ Dependent variable } \\
\cline { 3 - 5 } & & \multicolumn{1}{c}{ ROA } & \multicolumn{1}{c}{ ROE } & \multicolumn{1}{c}{ Reputation } \\
\hline High profile firms & Constant & -0.117 & -0.052 & -5921.812 \\
& CSR & $0.005^{* *}$ & $0.005^{* *}$ & $258.702^{* *}$ \\
\multirow{2}{*}{ Low profile firms } & & & & \\
& Constant & 0.029 & -0.176 & -9365.405 \\
& CSR & $-5.5 \mathrm{E}-005$ & $0.007 * *$ & $407.827^{* *}$ \\
\hline
\end{tabular}

**significant at $5 \%$

\subsection{Discussion}

The relationship between corporate social responsibility disclosure on ROA. Corporate Social Responsibility disclosure variable for high profile firms has significantly influence ROA. This result is in-line with Janra (2015) that shows that there is a relationship between CSR and profitability. Corporate Social Responsibility disclosure variable for low profile firms has no significantly influence ROA which in-line with Evandini and Harsono (2014), Purwanto (2011), and Khadifa and Chariri (2014).

The relationship between corporate social responsibility disclosure on ROE. Corporate Social Responsibility disclosure variable for high profile firms has significantly influence ROE. This result is in-line with Yuliawati dan Sukirman (2015) which show that Corporate Social Responsibility disclosure has significant effect on profitability. Corporate Social Responsibility disclosure variable for low profile firms has significantly influence ROE. This result is in-line with Yuliawati dan Sukirman (2015).

The relationship between corporate social responsibility disclosure on company's reputation. Corporate Social Responsibility disclosure variable for high profile firms has significantly influence Reputation. This result is in-line with Ayadi (2009), Yusdantara and Rahanatha (2015), and Syahriani and Siwi (2018). Corporate Social Responsibility disclosure variable for low profile firms has significantly influence reputation. This result is in-line with Ayadi (2009), Yusdantara and Rahanatha (2015), and Syahriani and Siwi (2018).

\section{CONCLUSION}

This study concludes that Corporate Social Responsibility disclosure for high profile firms significantly influence profitability (ROA), but Corporate Social Responsibility disclosure for low profile firms significantly not influence profitability (ROA). Corporate 
Social Responsibility disclosure for high profile firms significantly influence profitability (ROE), and Corporate Social Responsibility disclosure for low profile firms significantly influence profitability (ROE). Corporate Social Responsibility disclosure for high profile firms significantly influence reputation but insignificant for low profile firms.

This study suggests that for company management that it is expected to be more open in disclosing activities related to corporate social responsibility in its annual reports. The government and IAI (or Ikatan Akuntan Indonesia) are expected to be able to formulate a policy to make corporate social responsibility disclosure a mandatory disclosure given the low level of social responsibility disclosure. Further research is recommended to use a larger sample so that the results obtained are more convincing. Future studies are expected to be able to add or use other variables to find a standard model for corporate social responsibility disclosure. In subsequent studies, the study period should be more than 2 years so that research results are more accurate.

\section{REFERENCES}

Ambadar, J. (2008). Corporate Social Responsibility (CSR) dalam praktik di Indonesia. Jakarta: Elex Media Komputindo.

Anisah, H. N. (2018). Pengaruh kepemilikan manajerial, komite audit, ukuran dewan komisaris, profitabilitas, likuiditas, profil perusahaan, dan ukuran perusahaan terhadap pengungkapan Corporate Social Responsibility (CSR) dalam laporan tahunan (Studi pada perusahaan manufaktur yang terdaftar di Bursa Efek Indonesia periode 20142016). Skripsi. http://eprints.ums.ac.id/60740/1/9.\%20naskah\%20publikasi.pdf

Alkababji, M. W. (2014). Voluntary disclosure on corporate social responsibility: a study on the annual reports of Palestinian corporations. European Journal of Accounting Auditing and Finance Research, 2(4), 5982.https://www.eajournals.org/journals/european-journal-of-accounting-auditing-andfinance-research-ejaafr/vol-2no-4june-2014/voluntary-disclosure-corporate-socialresponsibility-study-annual-reports-palestinian-corporations-2/.

Aras, G., Aybars, A., \& Kutlu, O. (2010). Managing corporate performance Investigating the relationship between corporate social responsibility and financial performance in emerging markets. International Journal of Productivity and Performance Management 59(3), 229-254. https://doi.org/10.1108/17410401011023573.

Ayadi, S. D. (2009). Some determinants of social and environmental disclosures in annual reports by French firms.Accounting and Management Information Systems, 8(3), 324351. http://online-cig.ase.ro/jcig/papers.aspx?idc=1698.

Celvin, H., \& Gaol, R. L. (2015). Pengaruh pengungkapan Corporate Social Responsibility (CSR) terhadap profitabilitas perusahaan pertambangan yang terdaftar di Bursa Efek Indonesia. Jurnal Riset Akuntansi dan Keuangan, 1(2), 139166.https://media.neliti.com/media/publications/282768-pengaruh-pengungkapancoorporate-social-51f14c7a.pdf.

Evandini, C., \& Darsono. (2014). Faktor-faktor yang berpengaruh terhadap pengungkapan tanggung jawab sosial perusahaan pada perusahaan manufaktur yang terdaftar di BEI. Diponegoro Journal of Accounting, 3(3), 1-11. https://ejournal3.undip.ac.id/index.php/accounting/article/view/6060

Janra, D. M. (2015). Pengaruh kepemilikan manajerial, leverage, profitabilitas, dan ukuran perusahaan terhadap pengungkapan informasi pertanggungjawaban social perusahaan (Studi empiris pada perusaahaan manufaktur yang terdaftar di BEI 
tahun 2010-2013), Jurnal Akuntansi, $3(1), \quad$ 1-29.

http://ejournal.unp.ac.id/students/index.php/akt/article/view/1611

Jeffrey, S., Rosenberg, S., \& McCabe, B. (2018). Corporate social responsibility behaviors and corporate reputation, Social Responsibility Journal. https://doi.org/10.1108/SRJ11-2017-0255.

Indriantoro, N. \& Supomo, B. (2004). Metodologi penelitian bisnis untuk akuntansi dan manajemen. Yogyakarta: Badan Penerbitan Fakultas Ekonomi.

Khadifa, R. \& Chariri, A. (2014). Pengaruh kinerja lingkungan, size, profitabilitas, ukuran dewan komisaris, profile, leverage, dan konsentrasi kepemilikan perusahaan terhadap CSR disclosure di perusahaan manufaktur yang terdaftar di Bursa Efek Indonesia (BEI) tahun 2010-2012. Diponegoro Journal of Accounting, 3(4), 1-10. https://ejournal3.undip.ac.id/index.php/accounting/article/view/10283

Khan, Z. A. (2017). Profit maximisation as an objective of a firm - A Robust Perspective. International Journal of Research in Finance and Marketing, 7(6), 217-219. https://www.researchgate.net/publication/331465420_Profit_Maximisation_as_an_obj ective_of_a_firm-A_Robust_Perspective.

Priyanka, F. (2013). Pengaruh pengungkapan Corporate Social Responsibility (CSR) terhadap profitabilitas pada perusahaan high profile yang terdaftar di BEI periode 2009-2011. Skripsi.https://eprints.uny.ac.id/16259/

Purwanto, A. (2011). Pengaruh tipe industri, ukuran perusahaan, profitabilitas, terhadap Corporate Social Responsibility. JurnalAkuntansi dan Auditing, 8(1), 12 29.https://ejournal.undip.ac.id/index.php/akuditi/article/view/4344.

Rahayu, W. (2014).Pengaruh pengungkapan Corporate Social Responsibility (CSR) terhadap profitabilitas perusahaan (studi pada perusahaan sector pertambangan periode 20122013 yang terdaftar di Bursa Efek Indonesia), Jurnal Administrasi Bisnis, 17(2), 18.http://administrasibisnis.studentjournal.ub.ac.id/index.php/jab/article/view/700

Sartono, A. (2010). Manajemen keuangan: Teori dan aplikasi. Edisi 4. Yogyakarta: Badan Penerbitan Fakultas Ekonomi.

Sela, A. Y., Karamoy, H., \& Mawikere, L. M. (2019). Analisis penerapan akuntansi lingkungan pada RSUD DR. Sam Ratulangi Tondano. Indonesia Accounting Journal, 1(2), 63-73. https://doi.org/10.32400/iaj.26649.

Syahriani, D. \& Siwi, M. (2018). Hubungan komunikasi Corporate Social Responsibility dengan reputasi perusahaan. Jurnal Komunikasi Pembangunan, 16(1), 54-74. https://journal.ipb.ac.id/index.php/jurnalkmp/article/view/25121

Sutrisno, D. (2017). Pengaruh pengungkapan Corporate Social Responsibility dan profitabilitas terhadap nilai perusahaan (Studi empiris pada perusahaan yang tergabung dalam Indeks Sri Kehati yang Terdaftar di BEI Periode 2010-2014). Skripsi. http://digilib.unila.ac.id/26761/3/SKRIPSI\%20TANPA\%20BAB\%20PEMBAHASA N.pdf

Tanudjaja, B. B. (2006). Perkembangan Corporate Social Responsibility di Indonesia. Petra Christian University Surabaya. Nirmana, 8(2), 92-98. http://puslit2.petra.ac.id/ejournal/index.php/dkv/article/viewFile/17049/17013.

Utomo, M. M. (2000). Praktek pengungkapan social pada laporan tahunan perusahaan di Indonesia (Studi perbandingan antara perusahaan-perusahaan high profile dan low profile). Simposium Nasional Akuntansi III. Jakarta.

Wahongan, L. (2019). Effects of financial performance and corporate social responsibility on company values: case of banks listed on the Indonesia stock exchange. Journal Accountability, 8(2), 75-84. https://doi.org/10.32400/ja.24758.8.2.2019.75-84 
Wardani, M. K. P. W. (2015). Pengaruh pengungkapan Corporate Social responsibility terhadap profitabilitas perusahaan (Studi empiris pada perusahaan yang terdapat di Bursa Efek Indonesia Tahun 2010-2012). Skripsi. https://repository.usd.ac.id/995/2/112114019_full.pdf.

Widjaja, G., \& Pratama, Y. A. (2008). Hukum \& Bisnis Perusahaan Tanpa CSR. Jakarta: Forum Sahabat.

Wibisono,Y. (2007).Membedah konsep dan aplikasi CSR: Corporate Social Responsibility. Grasik: Fascho Publishing.

Yuliawati, R. \& Sukirman (2015). Faktor-faktor yang mempengaruhi pengungkapan Corporate Social Responsibility, Accounting Analisys Journal, 4(4), 1-9. https://journal.unnes.ac.id/sju/index.php/aaj/article/view/9119/5875

Yusdantara, I. K., \& Rahanatha, G. B. (2015). Pengaruh Corporate Social Responsibility terhadap reputasi perusahaan yang dimediasi oleh kepuasan pelanggan (Studi pada PT. Coca Cola Amatil Denpasar). E Journal Manajemen, 4(4), 813-831. https://ojs.unud.ac.id/index.php/Manajemen/article/view/11215. 